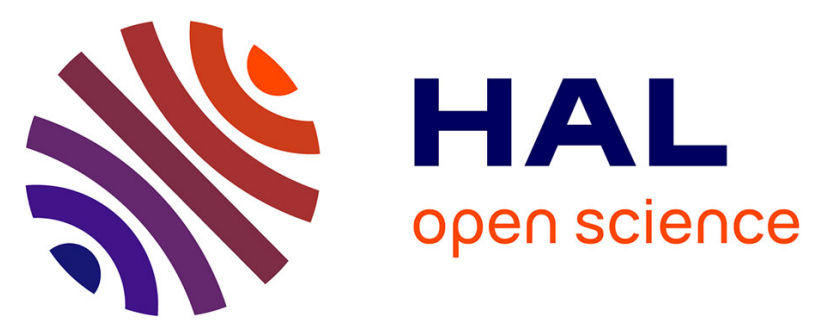

\title{
Genetic diversity of porcine reproductive and respiratory syndrome virus strains circulating in Hungarian swine herds
}

Gyula Balka, Ákos Hornyák, Ádám Bálint, István Kiss, Sándor Kecskeméti, Tamás Bakonyi, Miklós Rusvai

\section{To cite this version:}

Gyula Balka, Ákos Hornyák, Ádám Bálint, István Kiss, Sándor Kecskeméti, et al.. Genetic diversity of porcine reproductive and respiratory syndrome virus strains circulating in Hungarian swine herds. Veterinary Microbiology, 2007, 127 (1-2), pp.128. 10.1016/j.vetmic.2007.08.001 . hal-00532300

\section{HAL Id: hal-00532300 https://hal.science/hal-00532300}

Submitted on 4 Nov 2010

HAL is a multi-disciplinary open access archive for the deposit and dissemination of scientific research documents, whether they are published or not. The documents may come from teaching and research institutions in France or abroad, or from public or private research centers.
L'archive ouverte pluridisciplinaire HAL, est destinée au dépôt et à la diffusion de documents scientifiques de niveau recherche, publiés ou non, émanant des établissements d'enseignement et de recherche français ou étrangers, des laboratoires publics ou privés. 


\section{Accepted Manuscript}

Title: Genetic diversity of porcine reproductive and respiratory syndrome virus strains circulating in Hungarian swine herds

Authors: Gyula Balka, Ákos Hornyák, Ádám Bálint, István Kiss, Sándor Kecskeméti, Tamás Bakonyi, Miklós Rusvai

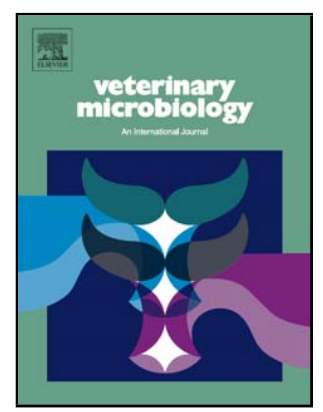

PII:

S0378-1135(07)00388-4

DOI: doi:10.1016/j.vetmic.2007.08.001

Reference: VETMIC 3779

To appear in: $\quad$ VETMIC

Received date: $\quad 23-5-2007$

Revised date: 24-7-2007

Accepted date: $\quad 2-8-2007$

Please cite this article as: Balka, G., Hornyák, Á., Bálint, Á., Kiss, I., Kecskeméti, S., Bakonyi, T., Rusvai, M., Genetic diversity of porcine reproductive and respiratory syndrome virus strains circulating in Hungarian swine herds, Veterinary Microbiology (2007), doi:10.1016/j.vetmic.2007.08.001

This is a PDF file of an unedited manuscript that has been accepted for publication. As a service to our customers we are providing this early version of the manuscript. The manuscript will undergo copyediting, typesetting, and review of the resulting proof before it is published in its final form. Please note that during the production process errors may be discovered which could affect the content, and all legal disclaimers that apply to the journal pertain. 
1 Genetic diversity of porcine reproductive and respiratory syndrome virus

2 $\underline{\text { strains circulating in Hungarian swine herds }}$

3

4 Gyula Balka ${ }^{\mathrm{a},{ }^{*}}$, Ákos Hornyák $^{\mathrm{b}}$, Ádám Bálint ${ }^{\mathrm{c}}$, István Kiss ${ }^{\mathrm{d}}$, Sándor Kecskeméti ${ }^{\mathrm{d}}$, 5 Tamás Bakonyi ${ }^{\mathrm{b}}$, Miklós Rusvai $^{\mathrm{a}}$

6

$7{ }^{a}$ Department of Pathology and Forensic Veterinary Medicine, Faculty of Veterinary Science,

8 Szent István University, István u. 2, H-1078 Budapest, Hungary

$9{ }^{b}$ Department of Microbiology and Infectious Diseases, Faculty of Veterinary Science, Szent

10 István University, Hungária krt. 23-25, H-1143 Budapest, Hungary

$11^{\mathrm{c}}$ Central Agricultural Office, Veterinary Diagnostic Directorate, Tábornok u. 2, H-1149

12 Budapest, Hungary

13 Central Agricultural Office, Veterinary Diagnostic Directorate, Institute of Debrecen,

14 Bornemissza u. 3-5, H-4031 Debrecen, Hungary

$15{ }^{*}$ Corresponding author. Tel.: +36 1478 4181; fax: +36 14784284.

16 E-mail address: balka.gyula@aotk.szie.hu (Gy. Balka).

17

18

19

20

21

22

23

Keywords: PRRSV, phylogenetic analysis, glycosilation 
24 Note: Nucleotide sequence data reported are available in the GenBank databases under the

25 accession numbers: DQ3666339 - DQ3666358, and EF406336 - EF406352.

\section{Abstract}

27

28 Analysis of 37 ORF5 sequences of Hungarian porcine respiratory and reproductive syndrome

29 virus (PRRSV) strains revealed that most of them (35) belonged to the European genotype, 30 forming distinct subgroups, reflecting the exceptional diversity of Eastern European strains.

31 Twelve vaccine-like strains were also found in non-vaccinated animals. Two strains belonged

32 to the American genotype showing 90-91\% nucleotide identity to the "Quebec" Canadian 33 reference strain. The analysis of the putative ectodomains and their $\mathrm{N}$-linked glycosylation 34 sites of the vaccine strain and its variants suggested selective pressure on the first ectodomain, 35 by a consistent amino acid change on epitope B and by loosing a glycosylation site in the 36 otherwise conserved N-46 position. 


\section{Introduction}

Porcine respiratory and reproductive syndrome (PRRS) is a widespread disease of swine characterised by reproductive disorders in gilts and sows and by respiratory signs, leading to death mostly in neonatal, suckling and weaned piglets. The porcine respiratory and reproductive syndrome virus (PRRSV) is an enveloped, single stranded RNA virus of the Arteriviridae family, member the order Nidovirales (Cavanagh et al., 1997). The genome of PRRSV is approximately 15 kilobases $(\mathrm{kb})$ in length, and comprises nine open reading frames (ORFs). ORF $1 \mathrm{a}$ and $1 \mathrm{~b}$ are coding for the enzymes responsible for the replication, ORF2a, and ORFs 3 to 5 are coding the membrane associated glycoproteins, ORF2b and ORF6 are encoding the nonglycosilated membrane proteins and the ORF7 codes for the nucleocapsid protein (Wu et al., 2001; Snijder and Meulenberg 1998).

One of the most variable region of the PRRSV genome is the ORF5 encoding the 25kDa glycoprotein 5 (GP5) (Andreyev et al., 1997). This glycoprotein forms a heterodimeric complex with the M protein (encoded by ORF6) via disulphide bound and is located in the membrane of the virion (Snijder et al., 2003). GP5 contains neutralization epitopes in its Nterminal ectodomain and is one of the targets of the protective anti-viral immunity, since antibodies produced against it can protect the animals from viraemia and the development of the characteristic PRRSV lesions (Pirzadeh and Dea 1997; Balasuriya and MacLahan 2004). Various sequence analyses have proven that there are marked genetic differences between the two major genotypes, the European and North American strains (Meng et al.,1995). In the past, European isolates were considered to be less variable than the American strains, however, recently significant differences were detected among the Eastern European strains supporting the definition of new genetic subtypes (Forsberg et al., 2002, Pesch et al., 2005, Stadejek et al., 2006). Genotypes forming a unique cluster were found in Lithuania and 
61 thought to be closely related to the common ancestors of the European and American strains

62 (Stadejek et al., 2002)

63 In Hungary only the presence of the European type sequences were reported so far 64 (Medveczky et al., 2001; Kiss et al., 2006). Considering the high diversity of the Eastern 65 European strains (Stadejek et al., 2002, 2006), including those surrounding Hungary (Indik et 66 al., 2005), and the observation that genetic variability might affect vaccination efficacy 67 (Labarque et al., 2004); the aim of this study was to detect and characterise PRRSV strains in 68 Hungary, and by comparing their ORF5 sequences, analyse their relationship to other 69 European and American isolates. Since European-type live virus vaccines are widely used in 70 Hungary, the presence of vaccine virus-like sequences in non vaccinated pigs of vaccinated 71 herds and their genetic stability was analysed by comparing them to the original vaccine 72 strains.

\section{2. Materials and methods}

75 2.1. Sample collection

76 Samples (lungs, were collected from pig farms located in different parts of Hungary, 77 between 2003 and 2006. (Description of the samples analysed in this study is given in Table 78 1.)

\subsection{RNA extraction and RT-PCR}

The RNA preparation from the supernatant of the centrifugated tissue homogenates, 82 and from the sera and semen samples was carried out using the QIAmp Viral RNA Mini Kit 83 (Qiagen, Hilden, Germany) according to the manufacturer's instructions. The RNA was 84 stored at $-80^{\circ} \mathrm{C}$ until used. 
85

86

The "diagnostic" primer pair (forward: 5'-CAGCCAGTCAATCARCTGTG-3' and reverse 5'-TCGCCCTAATTGAATAGGTG-3') was designed to amplify a part of the ORF7 and the 3' noncoding region (from nucleotide 14658 to 15050 on the Lelystad strain, accession number: M96262, and 14937 - 15364 on the American reference strain VR-2332, acc. number: NC_001961) and to be used for detecting both European and, if present, American sequences in clinical samples. The positive samples were further tested by amplifying the ORF5 sequences using primers 5'-GTTGCTSCATTTCMTGACAC-3' and 5'ATCGTCTAGGCCTCCCATTG-3' for the European strains (13416 - 14104 on the Lelystad strain); and 5'-ACCATGAGGTGGGCAACTGT-3' ${ }^{\prime}$ and ' TGGAGCCGTGCTATCATGAC-3' for the American strains (13721 - 14419 on VR-2332). The reverse transcription reactions (RTs) and the amplifications were performed by a continuous RT-PCR method using the Qiagen One-Step RT-PCR Kit (Qiagen, Hilden, Germany) at $52^{\circ}$ annealing temperature for 35 cycles.

\subsection{Sequencing and analysis of the sequence data}

The amplicons were sequenced using an ABI PRISM 3100 automatic sequencer. The chromatograms were visualised with the Chromas 2. software, and they were identified with BLAST (NCBI, Bethesda, USA), aligned by ALIGN PLUS 4 for Windows 95, version 4.0. Phylogenetic analyses were performed using the CLUSTAL X 1.81 software employing IUB DNA weight matrix with 0.5 transition ratio. Bootstrap resampling was carried out on 1000 replicate data sets. Phylogenetic trees were plotted with the TREEVIEW (Win32 version 1.6.6.) software. The N-linked glycosylation sites were determined with the NetNGlyc 1.0 server software (www.expasy.ch). 
110

\section{Results and discussion}

Large majority of the samples, that were positive after the "diagnostic", ORF7 RT-

PCR were squenced after amplifying a part of the ORF5 gene with the appropriate primers.

Altogether 37 ORF5 sequences were analysed obtained from 17 herds all over the country.

The nucleic acid sequences were aligned and compared to each other and to selected European and American strains. 35 of the 37 Hungarian strains belonged to the European genotype showing $92.54 \pm 1.93 \%$ average nucleotide identity (and standard deviation) to the Lelystad reference strain in the corresponding region of the genome. Strains HU12 and HU21 showed $86.80 \%$, and $85.87 \%$ nucleotide identity with the American reference strain VR-2332, respectively.

In one case (HU13), porcine alveolar macrophage (PAM) culture was prepared from the lungs of an apparently healthy piglet for further virus propagation. To test the cell culture before inoculation RNA was prepared from it and gave positive RT-PCR reaction when applying the "diagnostic" primers, hence confirmed the "genuine" PRRSV infection of the PAM cells. The aligned ORF5 sequence of the isolate from the PAM cells of the piglet differed only by one nucleotide, and one AA ( $\mathrm{g}_{13659}$ to a, resulting $\mathrm{D}_{56}$ to $\mathrm{U}$ ) from a Europeantype live vaccine strain. The mother of the piglet was vaccinated twice during gestation with this vaccine. Two other strains (HU14 and HU19) recovered from the same herd from healthy, non-vaccinated gilts, housed together with vaccinated sows had $98.84 \%$ nucleotide identity, $97.92 \%$ and $98.61 \%$ amino acid identity with the vaccine virus, respectively.

In an other case, amplicons from different positive samples collected in a seropositive herd were sequenced. In the herd two different European-type live vaccines were used one after the other (first "vaccine a", then "vaccine b", then "vaccine a" again). The samples were obtained in the third phase when "vaccine a" was used again. Analysing the results of the nucleotide sequencing we could identify strains showing $98.84-99.77 \%$ nucleotide identity 
135 with "vaccine b". All of these samples were lungs of aborted foetuses or piglets showing

136 severe respiratory symptoms before death. None of the piglets were vaccinated with any type

137 of vaccine, only their mothers were vaccinated twice with "vaccine a" during their gestation.

138 It is remarkable that "vaccine b" was detected from all the pigs 3-4 months after re-

139 introduction of "vaccine a" (Kiss et al., 2006).

140 A phylogenetic tree was constructed by using sequence data of amplicons from 71

141 strains: 37 Hungarian sequences, and a further 34 representatives of different genogroups,

142 deposited in the GenBank (Fig. 1). Strains used for the construction of the phylogenetic tree 143 are shown in Table 1.

144 In the phylogenetic tree the separation of the Hungarian strains resembling European

145 and American type PRRSV genotypes was supported by high bootstrap values: 35 of 37

146 strains were positioned among the European genotype, while strain HU12 and HU21 were

147 clustered within the American genotype. The Hungarian strains of the European genotype are

148 all clustered within Subtype 1 defined by Stadejek et al., (2006), and located in four different

149 subgroups, while one strain (HU16) was positioned alone. Subroup 4 was formed by 20

150 Hungarian strains, $54 \%$ of the strains investigated in this study. Within this subgroup the

151 separation of the strains was in correlation with the distance of the geographical location of

152 the herds where these samples were collected. All vaccine related strains of subgroup 1 and 2

153 were recovered from herds using European type live-virus vaccine. None of these animals

154 were vaccinated with any type of vaccine. These results suggested that the live vaccine-virus

155 strains were able to spread and circulate within the herd. Strain HU12 and HU21 are the first

156 identified strains in Hungary belonging to the American genotype. In Hungary the use of

157 American type vaccine is not authorised, and HU12 was detected in a herd which has

158 breeding contact with a Danish farm (boars are regularly introduced from Denmark).

159 Although in Denmark both genotypes are reported to be present (Madsen et al., 1998), the 
160 origin of these strains is unknown because they are more similar to the "Quebec" Canadian

161 reference strain (90\%, and 91\% nucleotide identity) than any American type MLV strain. The

162 herd where HU21 was detected is fattening weaned piglets of herd where HU12 was found.

163 Analysing the nucleic acid and the deduced amino acid identity values of the vaccine

164 related strains compared to live vaccine virus strains it is remarkable that in case of the

165 derivates of "vaccine b" all amino acid changes were found in the putative ectodomain,

166 consistently at the same amino acid positions (Fig. 2). The AA change at position 37 may also

167 affect the attachment of neutralizing antibodies, since this is the first amino acid of the

168 neutralizing epitope B (Balasuriya and MacLahan 2004; Ostrowski et al.,, 2002). Analysing

169 the putative N-linked glycosylation sites of the first ectodomain of the live vaccine virus

170 strains and their derivates, it was found that in case of "vaccine b" almost all the vaccine-like

171 variants lost the N-46 glycosylation site, by a consistent $\mathrm{N}$ to K AA change (compared to the

172 vaccine strain). Variability in this region is rare; since this part of the ectodomain is thought to

173 be extremely conserved (Pesch et al., 2005), and only few reports are found on wild type

174 strains without N-46 (Mateu et al., 2006; Stadejek et al., 2006). Vaccine-like strains lacking

175 N-46 are not reported so far. Strain HU08 is also without N-46. In an in vitro study the

176 infectivity of mutant PRRS viruses lacking oligosaccharide bound to N-46 exhibited a

177 significantly reduced infectivity compared to the wild type virus due to improper folding of

178 the GP5, which led to inefficient GP5-M heterodimerisation (Wissink et al., 2004). Loss of

179 glycan residues of the GP5 ectodomain enhances both the sensitivity of the viruses to in vitro

180 neutralization and the immunogenicity of the nearby neutralization epitopes (Ansari et al.,

181 2006). However all these strains lacking N-46 have a glycosylation site at AA position 37 (the

182 vaccine has N-35), which is thought to adopt the function of N-46 (Wissink et al., 2004). The

183 comparison of these variants to the parental, wild isolate, from which the vaccine was

184 prepared could possibly confirm the reversion of the vaccine, because all "vaccine b"-like 
185

186

187

188

189

190

191

192

193

194

195

196

197

sequences were recovered from aborted fetuses, or carcasses having severe respiratory problems prior to death (Table 1), and the economical losses caused by PRRS-like symptoms have extremely elevated after the introduction of this vaccine. Furthermore in an other herd where "vaccine a" was used alone the AA changes of the vaccine like strains were found in random distribution, all the "vaccine a"-like sequences were obtained from clinically healthy animals, and such losses were not observed within the herd. Comparing the nucleotide and the amino acid sequence alignments it is also remarkable that the incidence of the synonymous mutations in case of the vaccine-like strains is quite low. One might speculate that the explanation of this phenomenon could be the selective pressure of the immune system directed against the GP5 ectodomain, and indicates putative positive and negative selection sites on this part of the genome as observed previously by other investigators (Storgaard et al., 1999; Mateu et al., 2006). To avoid this selective pressure, those variants that have developed greater phenotypic differences (AA changes) compared to the original strain, had better chance to spread and persist within the herd while silent mutations were not rewarded by higher chances to multiply and spread. Detailed sequence analyses are needed in the future to identify the positive and negative selection sites, to verify the possible reversion of the vaccine virus or determine the cause of the increased losses after the introduction of the vaccine.

\section{Acknowledgements}

The work was supported by the Hungarian National Grants OTKA M041852, K62853, M02765 and D048647. 


\section{References}

2 Andreyev, V.G., Wesley, R.D., Mengeling, W.L., Vorwald, A.C., Lager, K.M,. 1997. Genetic

3 variation and phylogenetic relationships of 22 porcine reproductive and respiratory

4 syndrome virus (PRRSV) field strains based on sequence analysis of open reading frame 5. Arch. Virol. 142, 993-1001.

Ansari, I.H., Kwon, B., Osorio, F.A., Pattnaik, A.K., 2006. Influence of N-linked 7 glycosylation of porcine reproductive and respiratory syndrome virus GP5 on virus infectivity, antigenicity, and ability to induce neutralizing antibodies. J. Virol. 80, 39944004.

Balasuriya, U.B., MacLachlan, N.J., 2004. The immune response to equine arteritis virus: potential lessons for other arteriviruses. Vet. Immunol. Immunopathol. 102, 107-129.

Cavanagh, D., 1997. Nidovirales: a new order comprising Coronaviridae and Arteriviridae.

Forsberg, R., Storgaard, T., Nielsen, H.S., Oleksiewicz, M.B., Cordioli, P., Sala, G., Hein, J., Bøtner, A., 2002. The genetic diversity of European type PRRSV is similar to that of the

Indik, S., Schmoll, F., Sipos, W., and Klein, D., 2005. Genetic variability of PRRS virus in Austria: consequences for molecular diagnostics and viral quantification. Vet. Microbiol. 107, 171-179.

Kiss, I., Sámi, L., Kecskeméti, S., Hanada, K., 2006. Genetic variation of the prevailing porcine respiratory and reproductive syndrome viruses occurring on a pig farm upon vaccination. Arch. Virol. 151, 2269-2276.

Labarque, G., Van Reeth, K., Nauwynck, H., Drexler, C., Van Gucht, S., Pensaert, M., 2004. Impact of genetic diversity of European-type porcine reproductive and respiratory syndrome virus strains on vaccine efficacy. Vaccine 22, 4183-4190 
1 Madsen, K.G., Hansen, C.M., Madsen, E.S., Strandbygaard, B., Botner, A., Sorensen, K.J.,

2

3

4

5

6

7 1998. Sequence analysis of porcine reproductive and respiratory syndrome virus of the American type collected from Danish swine herds. Arch. Virol. 143, 1683-1700.

Mateu, E., Díaz, L., Darwich, L., Casal, J., Martín, M., Pujols, J., 2006. Evolution of ORF5 of Spanish porcine reproductive and respiratory syndrome virus strains from 1991 to 2005. Virus Res.115, 198-206.

Medveczky, I., Bálint, Á., Makranszky, L., Steverink, P., and Jacobs L., 2001. Sequence analysis of the membrane protein gene and nucleocapsid gene of porcine reproductive and respiratory syndrome virus isolated from a swine herd in Hungary. Acta Vet. Hung. 49, 237-244.

Meng, X.J., Paul, P.S., Halbur, P.G., and Lum, M.A., 1995. Phylogenetic analyses of the putative $\mathrm{M}$ (ORF6) and $\mathrm{N}$ (ORF7) genes of porcine reproductive and respiratory syndrome virus (PRRSV): Implication for the existence of two genotypes of PRRSV in the USA and Europe. Arch. Virol. 140, 745-755.

Meulenberg, J.J.M., 2000. PRRSV, the virus. Review article. Vet. Res. 31, 11-21.

Ostrowski, M., Galeota, J.A., Jar. A.M., Platt, K.B., Osorio, F.A., and Lopez O.J. 2002. Identification of neutralizing and nonneutraizing epitopes in the porcine reproductive and respiratory syndrome virus GP5 ectodomain. J. Virol. 76, 4241-4251.

Pesch, S., Meyer, C., Ohrlinger, V.F., 2005. New insights into the genetic diversity of European porcine reproductive and respiratory syndrome virus (PRRSV). Vet. Microbiol. 107, 31-48.

Pirzadeh, B., and Dea, S., 1997. Monoclonal antibodies to the ORF5 product of porcine reproductive and respiratory syndrome virus define linear neutralizing determinants. J. Gen. Virol. 78, 1867-1873. 
1 Snijder, E.J., Dobbe, J.C., Spaan, W.J.M., 2003. Heterodimerization of the two major 2 envelope proteins is essential for arterivirus infectivity. J. Virol. 77, 97-104.

3 Snijder, E.J., Meulenberg, J.J.M., 1998. The molecular biology of arteriviruses. J. Gen. Virol.

4

5

6 $\underline{83,961-979 .}$

Stadejek, T., Stankevicius, A., Storgaard, T., Oleksiewicz, M. B., Belák, S., Drew, T., and Pejsak, Z., 2002. Identification of radically different variants of porcine reproductive and respiratory syndrome virus (PRRSV) in Eastern Europe: Towards a common ancestor for European and American viruses. J. Gen. Virol. 83, 1861-1873.

Stadejek, T., Oleksiewicz, M.B, Potapchuk, D., Podgórska, K., 2006. Porcine reproductive and respiratory syndrome virus strains of exceptional diversity in eastern Europe support the definition of new genetic subtypes. J. Gen. Virol. 87, 1835-1841.

Storgaard, T., Oleksiewicz ,M.B., Bøtner, A., 1999. Examination of the selective pressures on a live PRRS vaccine virus. Arch. Virol. 83, 2389-1873.

Wissink, E.H.J., Kroese, M.V., Maneschijn-Bonsing, J.G., Meulenberg, J.J.M, van Rijn, P.A., Rijsewijk, F.A.M., Rottier, P.J.M., 2004. Significance of the oligosaccharides of the porcine reproductive and respiratory syndrome virus glycoproteins $\mathrm{GP}_{2 \mathrm{a}}$ and $\mathrm{GP}_{5}$ for infectious virus production. J. Gen. Virol. 85, 3715-3723.

Wu, W.H., Fang, Y., Farwell, R., Steffen-Bien, M., Rowland, R.R.R., Christopher-Hennings, J., and Nelson, E., 2001. A $10 \mathrm{kDa}$ structural protein of porcine reproductive and respiratory syndrome virus encoded by ORF2b. Virology 287, 183-191. 
$1 \quad$ Figure legends

2 Table 1. Viruses involved in the genetic investigations.

$4{ }^{*}$ Porcine alveolar macrophage culture prepared from an apparently healthy 10 day old piglet for purposes

5 of virus propagation but tested positive by PCR before inoculation

8 Figure 1. Phylogenetic tree based on the data of nucleotide sequences on the ORF 5 gene of 37 Hungarian

9 strains and 34 foreign strains. Abbreviations are indicated in Table 1. Bar on the right demonstrates the 10 genetic distance. Internal labels represent the bootstrap values of 1000 replicates.

11

12

13 Figure 2. Multiple alignment of the putative amino acid sequences of the vaccine derived PRRSV strains 14 between amino acid position 33 and 176 of the GP5 protein.

15

16 Bars under the sequence of the vaccine strains indicate putative N-linked glycosylation sites.

17 Boxes represent the ectodomains 1 and 2, and epitope B. 


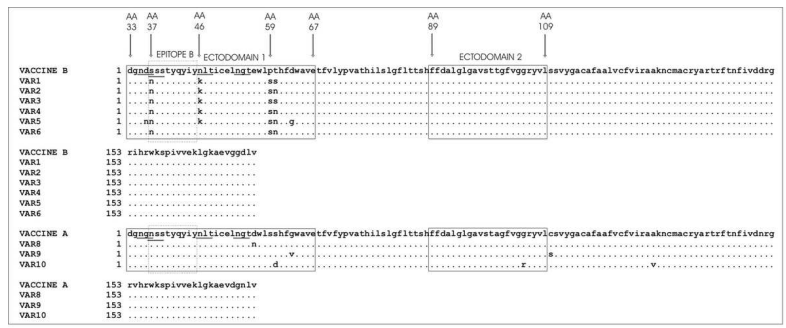

Page 14 of 16 


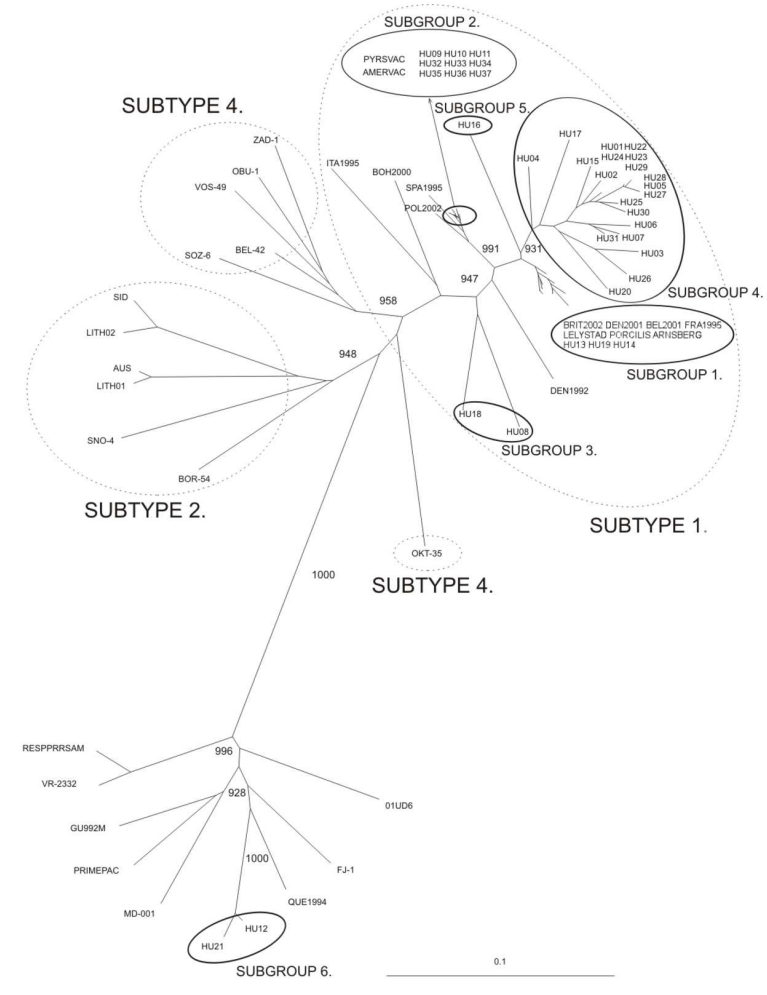

Page 15 of 16 


\begin{tabular}{|c|c|c|c|}
\hline Strain & Origin & $\begin{array}{l}\text { Date of sample } \\
\text { collection/ year of } \\
\text { submission }\end{array}$ & $\begin{array}{l}\text { GenBank acc. } \\
\text { number }\end{array}$ \\
\hline HU01 & lungs of an aborted fetus & 20.06.2003. & DQ3666339 \\
\hline HU02 & lungs of a dead fattening pig & 20.10 .2003 & DQ3666340 \\
\hline HU03 & tonsil of a dead weaned pig & 20.10 .2004 & DQ3666341 \\
\hline HU04 & lungs of a dead weaned pig & 13.10.2003. & DQ3666342 \\
\hline HU05 & lungs of a dead fattening pig & 30.07 .2004 & DQ3666343 \\
\hline HU06 & lungs of a dead fattening pig & 16.12.2004. & DQ3666344 \\
\hline HU07 & lungs of a dead fattening pig & 15.02 .2005 & DQ3666345 \\
\hline HU08 & lungs of an aborted fetus & 03.02 .2005 & DQ3666346 \\
\hline HU09 & lungs of an aborted fetus & 17.02.2005. & DQ3666347 \\
\hline HU10 & lungs of a dead weaned pig & 26.02 .2005 & DQ3666348 \\
\hline HU11 & lungs of an aborted fetus & 06.04 .2005 & DQ3666349 \\
\hline HU12 & serum of a healthy weaned pig & 11.05.2005. & DQ3666350 \\
\hline HU13* & healthy suckling piglet & 25.10 .2004 & DQ3666351 \\
\hline HU14 & serum of a healthy gilt & 25.10 .2004 & DQ3666352 \\
\hline HU15 & serum of an aborting sow & 14.06.2004. & DQ3666353 \\
\hline HU16 & lungs of a dead weaned pig & 26.11.2004. & DQ3666354 \\
\hline HU17 & serum of a weaned piglet & 10.03.2005. & DQ3666355 \\
\hline HU18 & lungs of a dead weaned pig & 02.12 .2004 & DQ3666356 \\
\hline HU19 & lungs of a dead weaned pig & 19.10.2004. & DQ3666357 \\
\hline HU20 & lungs of a dead weaned pig & 06.04 .2005 & DQ3666358 \\
\hline HU21 & lungs of a dead fattening pig & 22.09 .2006 & EF406336 \\
\hline HU22 & lungs of an aborted fetus & 11.09.2003. & EF406337 \\
\hline HU23 & lungs of an aborted fetus & 11.09.2003. & EF406338 \\
\hline HU24 & lungs of an aborted fetus & 18.09.2003. & EF406339 \\
\hline HU25 & lungs of a dead fattening pig & 20.10 .2003 & EF406340 \\
\hline HU26 & lungs of an aborted fetus & 15.10 .2004 & EF406341 \\
\hline HU27 & lungs of a dead weaned pig & 30.07 .2004 & EF406342 \\
\hline HU28 & lungs of a dead fattening pig & 15.09.2004 & EF406343 \\
\hline HU29 & lungs of a dead fattening pig & 15.09 .2004 & EF406344 \\
\hline HU30 & lungs of a dead weaned pig & 22.10 .2004 & EF406345 \\
\hline HU31 & lungs of a dead fattening pig & 16.12.2004. & EF406346 \\
\hline HU32 & lungs of a dead fattening pig & 16.12 .2004 & EF406347 \\
\hline HU33 & lungs of a dead fattening pig & 23.03 .2005 & EF406348 \\
\hline HU34 & lungs of a dead fattening pig & 23.03 .2005 & EF406349 \\
\hline HU35 & lungs of a dead fattening pig & 23.03 .2005 & EF406350 \\
\hline HU36 & lungs of a dead fattening pig & 14.11.2005. & EF406351 \\
\hline HU37 & lungs of a dead fattening pig & 14.11.2005. & EF406352 \\
\hline AMERVAC & Spain & 2006 & DQ324668 \\
\hline BEL2001 & Belgium & 2001 & AY035901 \\
\hline $\mathrm{BOH} 2000$ & Czech Rep. & 2000 & AF253537 \\
\hline BRIT2002 & England & 2002 & AF378799 \\
\hline DEN1992 & Denmark & 1998 & AJ223078 \\
\hline DEN2001 & Denmark & 2001 & AY035939 \\
\hline FRA1995 & France & 1996 & U40697 \\
\hline ARNSBERG & Germany & 2002 & AF378797 \\
\hline ITA1995 & Italy & 1996 & U40696 \\
\hline LELYSTAD & The Netherlands & 1993 & M96262 \\
\hline LITH01 & Lithuania & 2002 & AF378800 \\
\hline LITH02 & Lithuania & 2002 & AF378801 \\
\hline POL2002 & Poland & 2002 & AF378804 \\
\hline PORCILIS & The Netherlands & 2002 & AF378819 \\
\hline PRIMEPAC & U.S.A. & 1998 & AF066384 \\
\hline PYRSVAC & Spain & 2002 & AF378820 \\
\hline QUE1994 & Canada & 1995 & L40898 \\
\hline RESPPRRS & U.S.A. & 1998 & AF066183 \\
\hline SPA1996 & Spain & 1996 & U40690 \\
\hline VR-2332 & U.S.A. & 1995 & U87392 \\
\hline BEL-42 & Belarus & 2006 & DQ324669 \\
\hline BOR-54 & Belarus & 2006 & DQ324672 \\
\hline OBU-1 & Belarus & 2006 & DQ324676 \\
\hline OKT-35 & Belarus & 2006 & DQ324677 \\
\hline SNO-4 & Belarus & 2006 & DQ324683 \\
\hline SOZ-6 & Belarus & 2006 & DQ324686 \\
\hline VOS-49 & Belarus & 2006 & DQ324690 \\
\hline ZAD-1 & Belarus & 2006 & DQ324694 \\
\hline AUS & Lithuania & 2006 & DQ324667 \\
\hline SID & Lithuania & 2006 & DQ324682 \\
\hline FJ-1 & China & 2004 & AY881994 \\
\hline GU992M & Japan & 2005 & $\mathrm{AB} 175721$ \\
\hline MD-001 & Taiwan & 1998 & AF121131 \\
\hline 01UD6 & Thailand & 2004 & AY297113 \\
\hline
\end{tabular}

